\title{
ASSESSMENT OF CURATIVE EFFECT OF USING STEM CELLS ON THE CONTROL OF PESTICIDE DAMAGING EFFECT ON LIVER
}

\author{
Ragab, M. H. ${ }^{(1)}$; Rashed, Laila, A. ${ }^{(2)}$; Bassily, Nahed, S. ${ }^{(3)}$ \\ and Shirley R Henry ${ }^{(3)}$
}

1) Institute of Environmental Studies and Research Ain Shams University

2) Medical Biochemistry\& Molecular Biology, Faculty of Medicine, Cairo University 3) Department of Histopathology National Organization for drug Control and Research

\begin{abstract}
Introduction: Liver failure is a growing health problem and one of the main causes of death worldwide. Regenerative medicine as stem cells therapy is a newly rapidly developing field in which diseased tissues are regenerated.

Aim: To evaluate the effectiveness of stem cell on liver degeneration induced by Chlorpyrifos as an organophosphorus insecticide widely used in agriculture in Egypt, and Comparing its efficacy with silymarin and colchicine as antifibrotic agents used in liver fibrosis.

Methods: Induction of liver degeneration and fibrosis by Chlorpyrifos (CPF) for 8 weeks to Swiss albino mice in randomly divided groups (B, C and D) and a control healthy group (A), each group composed of 15 mice. Group (C) was treated with oral silymarin and colchicine and group (D) was treated with intra-peritoneal injection of Mesenchymal stem cells (MSC) (10 ${ }^{6}$ cells / mouse) after induction of liver fibrosis. After 4 weeks of treatment, all mice were sacrificed, blood was collected for chemical analysis (liver functions tests: Alanine aminotransferase (ALT), Aspartate aminotransferase (AST), Albumin, Bilirubin). Histopathological evaluation and grading were assessed by H\& E stain. Results: ALT, AST and Albumin were significantly improved in groups $\mathrm{C}$ and $\mathrm{D}$. Bilirubin and liver tissue grading were significantly reduced in group $\mathrm{D}$, with insignificant reduction in group $\mathrm{C}$.

Conclusion: Treatment with MSCs may improve liver functions tests (ALT, AST, Albumin, and Bilirubin) and liver fibrosis. While, treatment with
\end{abstract}


colchicine and silymarin does not improve the liver fibrosis, nor improves total serum bilirubin, but may improve ALT, AST and Albumin.

Keywords: Chlorpyrifos, Colchicine, Silymarin, Mesenchymal Stem Cells

\section{INTRODUCTION}

Chlorpyrifos $\quad(O, \quad O$-diethyl $\quad 0-[3, \quad 5, \quad 6$-trichloro-2-pyridinol phosphorothionate) is a broad-spectrum organophosphorus insecticide that widely used in agriculture and domestic pest control (Gralewicz et al., 2002). Toxicity associated with Chlorpyrifos led to the restriction of some of its domestic uses by United State Environmental Protection Agency in 2011. Despite its restriction, Chlorpyrifos still remains one of the most widely used insecticides (Steenland et al., 2000). Millions of people exposed to pesticides in the Eastern Mediterranean, an increasingly agricultural region. In Egypt, over 1 million children between the ages of 7 and 12 help with cotton pest management, exposing them to insecticides. Insecticides were the leading cause of deaths from poisonings. It is estimated that there are more than 15,000 tons of obsolete pesticide stocks in Africa, many of which are Persistent Organic Pollutants (POPs) as they do not break down in the environment and can enter the food chain through crops grown on contaminated sites and through fish from contaminated waters (WHO, 2016).

Chlorpyrifos (CPF) induce clinical, biochemical and histological alterations in exposed animals. It induce significant increase in the activities of ALT, AST and ALP (Alkaline Phosphatase) serum enzymes, and significant decrease in albumin level compared to the normal control rats (Heikal et al., 2013; Orabi et al., 2013). 
Colchicine and silymarin are well known drugs in the Egyptian market used as antifibrotic agents. Silymarin is the extract of the milk thistle seeds, while colchicine extracted from plants of the genus Colchicum (autumn crocus), both used as hepatoprotective agents. Silymarin prevent hepatic fibrosis through suppression of inflammation and hypoxia in the hepatic fibrogenesis (Jeong et al., 2005). The hepatoprotective effects of colchicine and silymarin were very similar in regard to the prevention of chronic liver damage (Favari and Pérez-Alvarez, 1997).

Federico et al., 2017 in his review concluded that silymarin has three important activities: anti-inflammatory, antioxidant and proapoptotsis, which represent the "functional triad" that allows for antagonizing the onset and the progression of mechanisms of damage that are responsible for the progression of hepatitis to cirrhosis and Hepatocellular Carcinoma.

Mesenchymal stem cells or multipotent mesenchymal stromal cells (MSCs) as an acceptable method for intervention of various pathological lesions have been extensively investigated in small animal models to treat acute and chronic liver injuries. Mechanisms of action are not clearly elucidated but may include their ability to differentiate into hepatocyte-like cells, to reduce inflammation, and enhance tissue repair at the site of injury (Wang et al., 2016; Papanikolaou et al., 2017).

By using specific culture conditions, some studies showed that MSCs undergo a phenotypic change; express genes typically expressed in hepatocytes, fulfill some metabolic functions similar to hepatocytes, and thus deduced that MSCs can transdifferentiate into hepatocyte-like cells in vitro (Wang et al., 2016). 
J. Environ. Sci.

Institute of Environmental Studies and Research - Ain Shams University

\section{MATERIALS AND METHODS}

Cross sectional Study on animal model for three months and ten days start at $28^{\text {th }}$ of July 2016. Six weeks male Swiss albino mice weighted $33 \pm 3$ grams. Mice were obtained from the animal house of the National Organization for Drug Control and Research (NODCAR), Egypt. The animals were randomly divided into four groups of 15 animals each. However, during the experiment 10 animals only were left in groups B, C, D due to the death induced by CPF.

1- First group $(\mathbf{A})=$ Control, normal, non-diseased mice in a healthy environment and good nutritional status to be compared with the diseased and treated groups.

2- Second group $(\mathbf{B})=$ Diseased mice, Chlorpyrifos oral administration $\left(\mathrm{LD}_{50} / 80^{\text {th }}\right.$ of $60 \mathrm{mg} / \mathrm{Kg}$ Body Weight/ 3 times per week) for 8 weeks for induction of chronic liver disease (degeneration and fibrosis) according to Sharma et al., 2013.

3- Third group $(\mathbf{C})=$ Treated with combination of oral silymarin $(150 \mathrm{mg} /$ Kilogram body weigth) and colchicine (200 $\mu \mathrm{g} /$ Kilogram body weight) three times per week for four weeks after induction of liver degeneration and fibrosis with chlorpyrifos.

4- Fourth group (D) = Treated with bone marrow derived mesenchymal stem cells (single intra-peritoneal injection of labeled BM-MSC $10^{6}$ cells/ mouse intra-peritoneal) after induction of liver degeneration and fibrosis with chlorpyrifos. 
- Bone Marrow Derived Mesenchymal Stem cells preparation (BMMSCs): The femurs and tibias of six weeks old male Swiss albino mice were carefully dissected away from attached soft tissue, the ends of the bones were cut, and the bone marrow was aseptically flushed with Dulbecco's modified Eagle's medium (DMEM, GIBCO/BRL). Nucleated cells were isolated and re-suspended in complete culture medium supplemented with $1 \%$ penicillin-streptomycin (GIBCO/BRL). All cells were incubated at $37^{\circ} \mathrm{C}$, in an atmosphere of $5 \%$ humidified $\mathrm{CO}_{2}$ for 14 days. When cells grew to $80 \%$ confluency, they were harvested with $0.25 \%$ trypsin and $1 \mathrm{mmol} / \mathrm{L}$ ethylene-diamine-tetra-acetic acid (EDTA) (GIBCO/BRL) for $5 \mathrm{~min}$ at $37^{\circ} \mathrm{C}$. After centrifugation, cells were resuspended with serum-supplemented medium and incubated in $50 \mathrm{~cm}$ culture flask (Falcon). The resulting cultures were referred to as firstpassage cultures (Alhadlaq and Mao, 2004).

- Labeling of BM-MSCs with PKH26 Fluorescent Dye: BM-MSCs were labeled with PKH26 Fluorescent Dye (Sigma-Aldrich, Saint Louis, MO) to be detected easily in liver tissue by fluorescent microscope. Cells were first centrifuged, washed twice in serum-free medium and were pelleted and suspended in dye solution. Cells were injected intra-peritoneal into mice group D with $10^{6}$ cells per mouse intra-peritoneal. After four weeks, liver tissues were examined with a fluorescence microscope to detect the cells (Abdel Aziz et al., 2011).

After 4 weeks of treatment, animals were sacrificed 
- Collection of samples:

1- Blood: were collected from retro-orbital venous plexus in vials containing heparin $(10 \mathrm{IU} / \mathrm{ml})$ and centrifuged at $1500 \mathrm{rpm}$ for 15 minutes for plasma separation. Chemical analysis (ALT, AST, Albumin, and Bilirubin) was done by a colorimetric method for all animals groups and results were listed for statistical analysis.

2- Liver organs: At the time of sacrifice, anatomical dissections were done for all animal groups and liver tissue samples were collected and fixed in $10 \%$ neutral buffered formaldehyde for 24 hours. To stabilizes tissue proteins and prevent further changes.

\section{- Histopathological analysis:}

Conventional tissue processing was proceeded. The blocks of wax were sectioned by the microtome into thin sections $(5 \mu)$ then stained with Haematoxylin and eosin stain (H\&E). Scoring was estimated to every group according to Ishak et al., 1995.

\section{RESULTS}

- Biochemical parameters: Results and significance of the effect of chlorpyrifos exposure and treatment on liver functions profile of albino mice are shown in Tables $(1 \& 2)$. 
Table (1): The relations of ALT, AST, Albumin and Bilirubin of the groups $\mathrm{A}, \mathrm{B}, \mathrm{C}$ and D:

\begin{tabular}{|c|c|c|c|c|c|}
\hline Groups & No. & $\begin{array}{c}\text { ALT产 } \\
\pm \text { SD }\end{array}$ & $\begin{array}{c}\text { AST } \overline{\mathbf{X}} \\
\pm \text { SD }\end{array}$ & $\begin{array}{l}\text { Albumin } \overline{\bar{X}} \\
\pm \text { SD }\end{array}$ & $\begin{array}{c}\text { Bilirubin } \overline{\bar{X}} \\
\quad \pm \text { SD }\end{array}$ \\
\hline Group A & 15 & $18.1 \pm 1.6$ & $27.1 \pm 2.4$ & $3.8 \pm 0.3$ & $0.7 \pm 0.2$ \\
\hline Group $\mathrm{B}$ & 10 & $67.7 \pm 4.1$ & $100.2 \pm 6.1$ & $2.6 \pm 0.2$ & $1.9 \pm 0.3$ \\
\hline Group $\mathrm{C}$ & 10 & $43.2 \pm 3.7$ & $64.9 \pm 5.3$ & $2.9 \pm 0.2$ & $1.7 \pm 0.1$ \\
\hline Group D & 10 & $36.3 \pm 2.5$ & $55.0 \pm 3.8$ & $3.2 \pm 0.1$ & $1.1 \pm 0.1$ \\
\hline
\end{tabular}

Group A = Control

Group B = Chlorpyrifos exposure $(\mathrm{CPF})$ only.

Group $\mathrm{C}=$ Chlorpyrifos exposure and treated with Antifibrotic drugs (Colchicine and Silymarin)

Group D = Chlorpyrifos exposure and treated with Mesenchymal stem cell (MSC)

S.D = Stander deviation

$\overline{\mathrm{X}}=$ mean

ALT $=$ Alanine aminotransferase enzyme

$\mathrm{AST}=$ Aspartate aminotransferase enzyme

Table (2): Multiple Statistical Comparisons between all groups A, B, C and

D by ANOVA tests:

\begin{tabular}{|c|c|c|c|c|c|}
\hline Groups & Grouping & $\begin{array}{l}\text { P value } \\
\text { of ALT }\end{array}$ & $\begin{array}{l}\text { P value } \\
\text { of AST }\end{array}$ & $\begin{array}{l}\text { P value of } \\
\text { Albumin }\end{array}$ & $\begin{array}{l}\text { P value of } \\
\text { Bilirubin }\end{array}$ \\
\hline \multirow{3}{*}{ Group A } & Group B & "0.001* & $0.001 *$ & "0.001* & "0.001* \\
\hline & Group C & $0.001 *$ & $0.001 *$ & $0.001 *$ & $0.001 *$ \\
\hline & Group D & $0.001 *$ & $0.001 *$ & $0.001 *$ & $0.001 *$ \\
\hline \multirow{3}{*}{ Group B } & Group A & $0.001 *$ & $0.001^{*}$ & $0.001^{*}$ & $0.001 *$ \\
\hline & Group C & $0.001 *$ & $0.001 *$ & $0.002 *$ & 0.086 \\
\hline & Group D & $0.001 *$ & $0.001 *$ & $0.001 *$ & $0.001 *$ \\
\hline \multirow{3}{*}{ Group C } & Group A & $0.001^{*}$ & $0.001^{*}$ & $0.001^{*}$ & $0.001^{*}$ \\
\hline & Group B & $0.001 *$ & $0.001^{*}$ & $0.002 *$ & 0.086 \\
\hline & Group D & $0.001 *$ & $0.001 *$ & $0.002 *$ & $0.001 *$ \\
\hline \multirow{3}{*}{ Group D } & Group A & $0.001 *$ & $0.001^{*}$ & $0.001^{*}$ & $0.001^{*}$ \\
\hline & Group B & $0.001 *$ & $0.001 *$ & $0.001 *$ & $0.001 *$ \\
\hline & Group C & $0.001 *$ & $0.001 *$ & $0.002 *$ & $0.001 *$ \\
\hline
\end{tabular}

*Significant 
The daily oral administration of chlorpyrifos led to significant elevation in the level of ALT, AST and Bilirubin with decreased albumin level. While in treated group C the enzymes (ALT \&AST) were lesser than group B but around triple the Control group, and in MSCs treated group (group D) the enzymes was significant lesser than group B and C. ANOVA tests were significant between all groups and $\mathrm{P}<0.001$ (Table 2).

Albumin in group C was very low to control group, while in MSC treated group it was nearly normal, close to control group. ANOVA tests were significant between all groups and $\mathrm{P}<0.001$ (Table 2).

In group $\mathrm{C}$, Bilirubin was significant high to control group, while in MSCs treated group it was lower than group B and C. ANOVA test were significant between all groups and $\mathrm{P}<0.001$. Except, the relations between groups $\mathrm{B}$ and $\mathrm{C}$ were insignificant (Table 2).

These deduce that, treatment with mesenchymal stem cells therapy improves liver functions tests (ALT, AST, Albumin, and Bilirubin). While, treatment with colchicine and silymarin does not improve total serum bilirubin, but improves ALT, AST and Albumin.

- Pathological evaluation: Eight weeks of oral chlorpyrifos (group B) induced liver degeneration and fibrosis. Showed necrosis and vacuolar degeneration (yellow arrow) of zone 3 cells with pyknotic nuclei, fatty changes varies from droplets to diffuse involvement of liver cells with displacement of the nuclei, bile duct proliferation, marked inflammatory activity in portal zone, and appearance of congested blood vessels (black arrow) with moderate fibrosis and loss of hepatic architecture (Figure 2). 
While liver sections from control group (group A) revealed normal hepatocytes arranged in parallel plates radiating from the central vein with large bright and vesicular nuclei, no inflammatory cells in the peri-portal areas and normal liver sinusoids (Figure 1).

Treatment with colchicine and silymarin (group C) as a standard therapy did not show any reduction in the fibrosis, and there were ballooning hepatocytes with vacuolar degeneration and pyknotic nuclei (yellow arrow), moderate portal inflammatory activity (black arrow) and loss of architecture (Figure 3).

Treatment with BM-MSCs (group D) was markedly reduced in the extent of portal cellular infiltration (black arrow) and reduced congestion with improving of hepatocytes degeneration and restoration of liver architecture (yellow arrow) (Figure 4).

\section{- Ishak scoring for these groups in H\& E Stain was as follows:}

Group A (HAI 0, F 0) indicated no inflammatory reaction with no fibrosis.

Group B (HAI 15, F 3) indicated sever inflammatory reactions with moderate fibrosis.

Group C (HAI 11, F 3) indicated moderate inflammatory reactions with moderate fibrosis.

Group D (HAI 6, F 1) indicated mild inflammatory reactions with mild fibrosis.

These deduce that, treatment with bone marrow derived mesenchymal stem cells therapy reduce liver fibrosis and improves liver functions tests (ALT, AST, Albumin, and Bilirubin). While, treatment with colchicine and 
silymarin do not improve the liver fibrosis, nor improve the total serum bilirubin, but improve ALT, AST and Albumin.

\section{DISSCUSSION}

In this study, the regenerative effect of BM-MSCs on hepatic degeneration and fibrosis induced by chronic organophosphorus poisoning (Chlorpyrifos) was investigated and compared its effects with known antifibrotic drugs (colchicine + silymarin).

\section{- The major findings of our study are:}

1- Intra-peritoneal administration of BM-MSCs $\left(10^{6}\right.$ cells/ mouse $)$ recovered liver functions, architectural changes and fibrous tissue degradation by increasing liver regeneration.

2- Colchicine and Silymarin recovered liver functions (ALT, AST, and Albumin), but not recovered bilirubin level nor liver fibrosis. This deduce that, colchicine and silymarin had regenerative effects on hepatocytes themselves with decreasing inflammatory reaction in portal tracts with no effect on collagen deposition in liver neither cholestasis.

Biochemical evaluation due to long term exposure to CPF (group B) led to significant elevation of serum liver enzymes (ALT, AST) indicate degeneration of hepatocytes, with significant elevation of serum bilirubin level which indicate cholestatic liver disease due to fibrosis of portal tracts with obstructions of bile flow from chronic toxicity, and significant reduction of serum albumin level due to loss of synthetic function of liver tissue in comparison to control group (A). These results were in consistence with previous reports by Heikal et al., 2013 and Orabi et al., 2013. 
Through H\&E staining in $\mathrm{CPF}$ group, histological evaluation was performed, showed necrosis and vacuolar degeneration with loss of liver architecture and appearance of congested blood vessels with moderate fibrosis around portal tracts. Ishak scoring was (HAI 15, F3) indicated sever inflammatory reactions with moderate fibrosis. These confirm chronic toxicity of CPF effects on liver tissue. This finding agreed with Sharma et al., 2013.

Treating liver degeneration and fibrosis by BM-MSCs was evaluated after four weeks of BM-MSCs transplantation (group D) to make sure homing took place as previously reported (Yu et al., 2012). We detected PKH26-labeled BM-MSCs in the injured liver tissue of recipient mice. Biochemical evaluation led to significant reduction of serum liver enzymes (ALT, AST) indicate regeneration of hepatocytes, with significant reduction of serum bilirubin level which indicate improvement of the cholestatic liver disease (reduction of fibrosis of portal tracts), and significant elevation of serum albumin level due to improvement of synthetic function of liver tissue in comparison to CPF group (B). These results suggest a possible therapeutic role of BM-MSCs in fibrotic liver injury, this consistent with previous studies of severe hepatic and renal damage (Quintanilha et al., 2013; Li et al., 2014). Histological evaluation in this group (D) indicated significant improvement of hepatic fibrosis compared to the untreated CPF group. There was markedly reduction in the extent of portal cellular infiltration and reduced congestion with improving of hepatocytes degeneration and restoration of liver architecture. There was a clear histological variability of severity within fibrosis and inflammatory activities classified by the Ishak scoring system as 
HAI 15, F 3 in group B and HAI 6, F 1 in group D. These results were in consistence with previous studies (Gaia et al., 2006; Gordon et al., 2006).

Biochemical evaluation of group $\mathrm{C}$ (treated with colchicine and silymarin) resulted in significant reduction of serum liver enzymes (ALT, AST) indicated regeneration of hepatocytes, and significant elevation of serum albumin level due to improvement of synthetic function of liver tissue with insignificant reduction of serum bilirubin level which indicated the presence of the fibrous tissue around portal tracts without degradation in comparison to CPF group (B). This finding was consistent with Láng et al., 1990. But, they did not consistent with Fried et al., 2012. Histopathological evaluation of this group resulted in insignificant reduction in the fibrosis, and there were ballooning hepatocytes with vacuolar degeneration with decreased portal inflammatory activity and loss of architecture. Ishak scoring for this group was (HAI 11, F 3) indicated moderate inflammatory reactions with moderate fibrosis. These results suggest that there was a role of colchicine and silymarin in liver inflammation, but not in liver fibrosis and cholestatic liver disease. These results were in agreement with Muriel et al., 2005. But, they did not consistence with previous report of Morazzoni and Bombardelli, 1995.

\section{CONCLUSION}

The use of BM- MSCs as cell therapy improving liver functions and fibrosis in chronic liver disease. But treatment with Colchicine and Silymarin had insignificant antifibrotic effect on liver fibrosis and bilirubin, with 
significant improvement of liver enzymes (ALT, AST) and synthesis (Albumin).

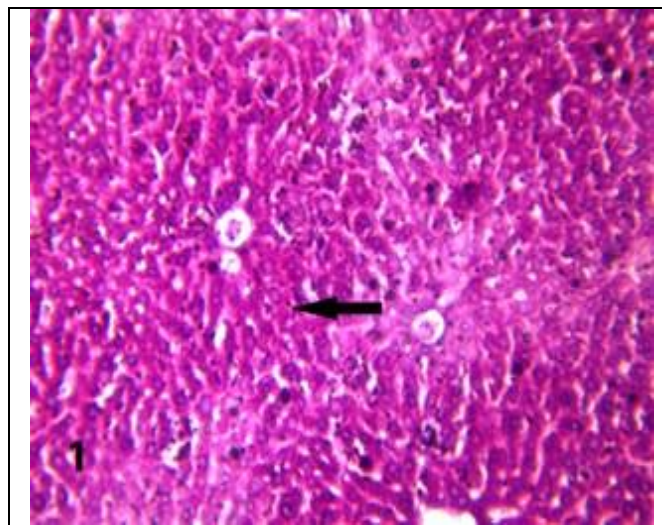

Figure (1): H \& E stain of liver tissue Group A showing normal liver architecture (black arrow) with no inflammatory cells nor fibrosis, at X 200

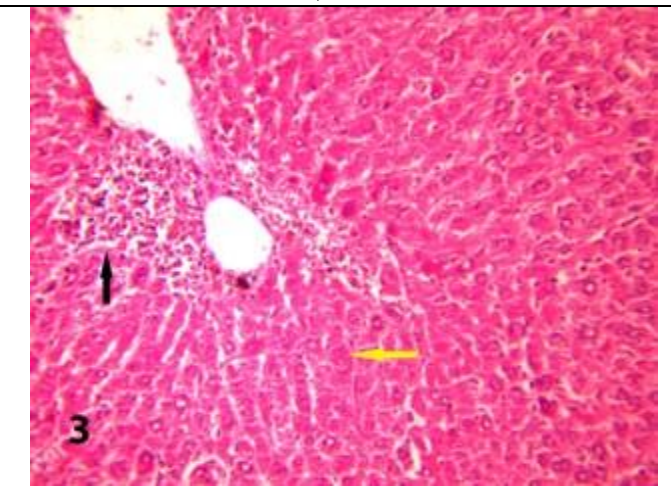

Figure (3): H \& E stain of liver tissue Group C showing ballooning hepatocyte with vacuolar degeneration and pyknotic nuclei (yellow arrow), moderate portal inflammatory activity (black arrow), at X 200

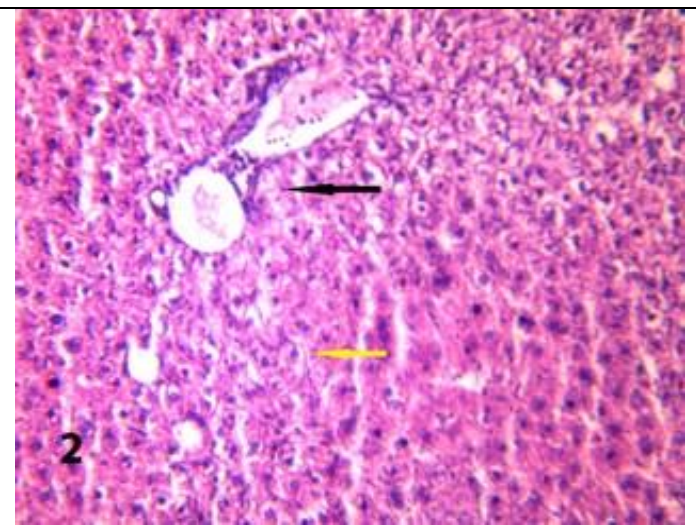

Figure (2): H \& E stain of liver tissue Group B showing vacuolar necrosis and degeneration and pyknotic nuclei (yellow arrow), congested blood vessel (black arrow), at X 200

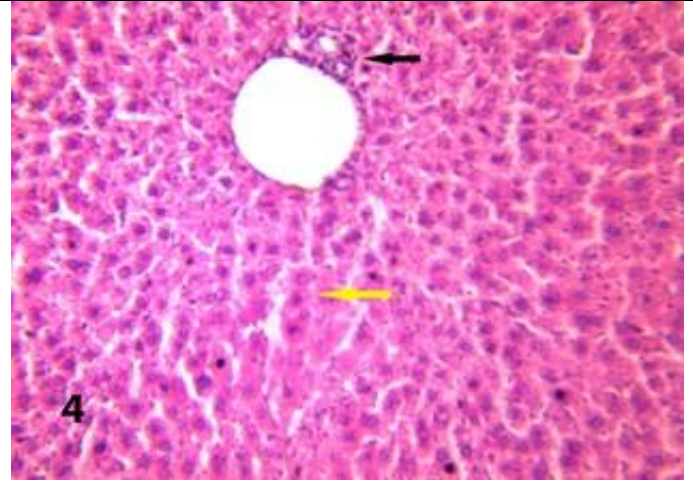

Figure (4): H \& E stain of liver tissue Group D showing mild portal cellular infiltration (black arrow), healthy hepatocytes with large bright and vesicular nuclei (yellow arrow), at X 200 


\section{REFERENCES}

Abdel Aziz, M. T.; Wassef, M. A.; Rashed, L. A.; Mhfouz, S.; Omar, N. and Elsebaie, M. M. (2011): Mesenchymal stem cells therapy in acute renal failure: possible role of hepatocyte growth factor. J. Stem Cell Res. Ther., 1, 109-15.

Alhadlaq, A. and Mao, J. J. (2004): Mesenchymal stem cells: isolation and therapeutics. Stem Cells Dev., 13, 436-48.

Favari, L. and Pérez-Alvarez, V. (1997): Comparative effects of colchicine and silymarin on CCl4-chronic liver damage in rats. Arch. Med. Res., 28 (1), 11-7.

Federico, A.; Dallio, M. and Loguercio, C. (2017): Silymarin/Silybin and Chronic Liver Disease: A Marriage of Many Years. Molecules, 22:191.

Fried, M. W.; Navarro, V. J.;Afdhal, N.; Belle, S. H.; Wahed, A. S.; Hawke, R. L.; Doo, E.; Meyers, C. M.; Reddy, K. R. (2012) and Silymarin in NASH and $\mathrm{C}$ Hepatitis (SyNCH) Study Group: Effect of silymarin (milk thistle) on liver disease in patients with chronic hepatitis $\mathrm{C}$ unsuccessfully treated with interferon therapy: a randomized controlled trial. JAMA, 308(3), 274-282.

Gaia, S.; Smedile, A.; Omedè, P.; Olivero, A.; Sanavio, F.; Balzola, F.; Ottobrelli, A.; Abate, M. L.; Marzano, A.; Rizzetto, M. and Tarella, C. (2006): Feasibility and safety of G-CSF administration to induce bone marrow-derived cells mobilization in patients with end stage liver disease. J. Hepatol., 45, 13-19.

Gordon, M. Y.; Levicar, N.; Pai, M.; Bachellier, P.; Dimarakis, I.; Al-Allaf, F.; M'Hamdi, H.; Thalji, T.; Welsh, J. P.; Marley, S. B.; Davies, J.; Dazzi, F.; Marelli-Berg, F.; Tait, P.; Playford, R.; Jiao, L.; Jensen, S.; Nicholls, J. P.; Ayav, A.; Nohandani, M.; Farzaneh, F.; Gaken, J.; Dodge, R.; Alison, M.; Apperley, J. F.; Lechler, R. and Habib, N. A. (2006): Characterization and clinical application of human CD34+ stem/ progenitor cell populations mobilized into the blood by granulocyte colony-stimulating factor. Stem cells, $24,1822-1830$. 
Gralewicz, S.; Lutz, P. and Tomas, T. (2002): Behavioural responsiveness to amphetamine or scopolamine following repeated exposure to chlorphenvinphos in rats. Acta Neurobiol. Exp., 62, 75-83.

Heikal, T. M.; Mossa, A. H.; Abdel Rasoul, M. A. and Marei, G. I. K. H. (2013): The Ameliorating Effects of Green Tea Extract against Cyromazine and Chlorpyrifos induced liver toxicity in male rats. Asian J. Pharm. Clin. Res., 6 (1), 48-55.

Ishak, K.; Baptista, A.; Bianchi, L.; Callea, F.; De Groote, J.; Gudat, F.; Denk, H.; Desmet, V.; Korb, G. and MacSween, R. N. (1995): Histological grading and staging of chronic hepatitis. J Hepatol, 22: 696-699

Jeong, D. H.; Lee, G. P.; Jeong, W. I.; Do, S. H.; Yang, H. J.; Yuan, D. W.; Park, H. Y.; Kim, K. J. and Jeong, K. S. (2005): Alterations of mast cells and TGF- $\beta 1$ on the silymarin treatment for CCl4induced hepatic fibrosis. World J. Gastroenterol., 11 (8), 11411148.

Láng, I.; Nékám, K.; Deák, G.; Mũzes, G.; González-Cabello, R.;Gergely,

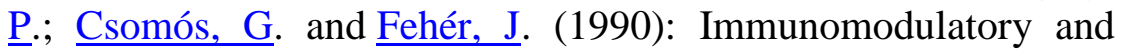
hepatoprotective effects of in vivo treatment with free radical scavengers. Ital. J. Gastroenterol., 22, 283-7.

Li, Y.; Yan, M.; Yang, J.; Raman, I.; Du, Y.; Min, S.; Fang, X.; Mohan, C. and Li, Q. Z. (2014): Glutathione S-transferase $\mathrm{Mu}$ 2-transduced mesenchymal stem cells ameliorated anti-glomerular basement membrane antibody-induced glomerulonephritis by inhibiting oxidation and inflammation. Stem Cell Res. Ther., 5, 19.

Morazzoni, P. and Bombardelli, E. (1995): Silybum marianum (Carduus marianus). Fitoterapia, 66, 3-42.

Muriel, P.; Moreno, M. G.; Hernández Mdel, C.; Chávez, E. and Alcantar, L.K. (2005): Resolution of liver fibrosis in chronic CCl4 administration in the rat after discontinuation of treatment: effect of silymarin, silibinin, colchicine and trimethylcolchicinic acid. Basic Clin. Pharmacol. Toxicol., 96 (5), 375-380.

Orabi, S. H.; Elbialy, B. E. and Shawky, S. M. (2013): Ameliorating and Hypoglycemic Effects of Zinc Against Acute Hepatotoxic Effect of Chlorpyrifos. Global Veterinaria, 10 (4), 439-446. 
Papanikolaou, I. G.; Katselis, C.; Apostolou, K.; Feretis, T.; Lymperi, M.; Konstadoulakis, M. M.; Papalois, A. E. and Zografos, G. C. (2017): Mesenchymal Stem Cells Transplantation following Partial Hepatectomy: A New Concept to Promote Liver Regeneration-Systematic Review of the Literature Focused on Experimental Studies in Rodent Models. Hindawi, Stem Cells International, Article ID 7567958, 22 pages.

Quintanilha, L. F.; Takami, T.; Hirose, Y.; Fujisawa, K.; Murata, Y.; Yamamoto, N.; Goldenberg, R. C. D. S.; Terai, S. and Sakaida, L. I. (2013): Canine mesenchymal stem cells show antioxidant properties against thioacetamide-induced liver injury in vitro and in vivo. Hepatol. Res., 44, E206-E217.

Sharma, A.; Sodhi, S.; Brar, A. S. and Ghai, J. K. (2013): Chlorpyrifosinduced hematological, biochemical and histoarchitectural alterations in albino mice. International Journal of Advanced Research, 1 (10), 825-835.

Steenland, K.; Dick, R. B.; Howell, R. J.; Chrislip, D. W.; Hines, C. J.; Reid, T. M.; Lehman, E.; Laber, P.; Krieg, E. F. and Knott, C. (2000): Neurologic function among termiticide applicators exposed to chlorpyrifos. Environ. Health Perspect., 108(4), 293-300.

United State Environmental Protection Agency (2011): Chlorpyrifos Preliminary Human Health Risk Assessment for Registration Review (US EPA) (2011-06-30), https://www.epa.gov/.

Wang, Y.; Yu, X.; Chen, E. and Li, L. (2016): Liver-derived human mesenchymal stem cells: a novel therapeutic source for liver diseases. Stem Cell Research \& Therapy, 7, 71.

W.H.O., World Health Organization (2016): Health environment for children alliance. Children's vulnerability to pesticides. www.who.int/heca/.

Yu, J.; Cao, H.; Yang, J.; Pan, Q.; Ma, J.; Li, J.; Li, Y.; Wang, Y. and Li, L. (2012): In vivo hepatic differentiation of mesenchymal stem cells from human umbilical cord blood after transplantation into mice with liver injury. Biochem. Biophys. Res. Commun., 422, 53945 . 


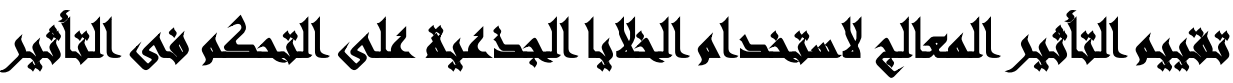

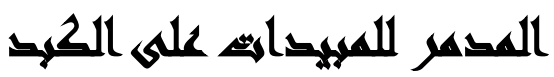

[r]

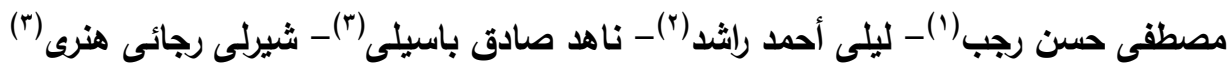

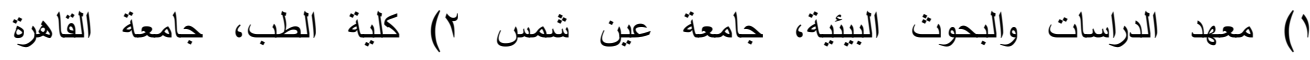
r) الهيئة القومية للرقابة والبحوث الدوائية

\section{المسريلتس}

مقدمة: الفنشل الكبدى مشكلة صحية متزايدة وواحد من الأسباب الرئيسية للوفاة فى العالم. فمن

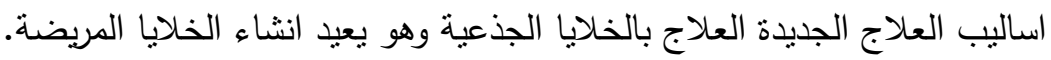

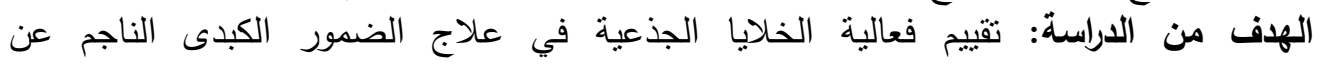

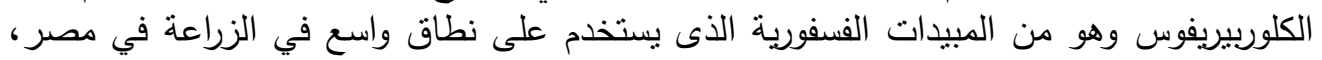

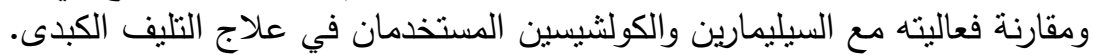
خطوات العمل: استقراء ضمور وتليف الكبد بالكلوربيريفوس لفئران ألبينو سويسرية في مجموعات التين

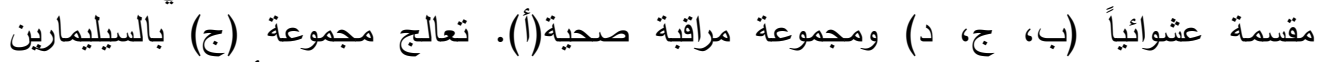

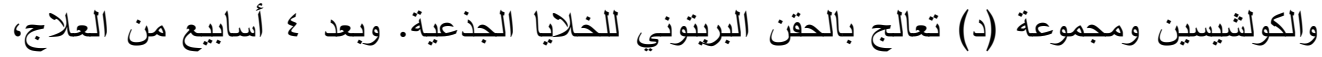

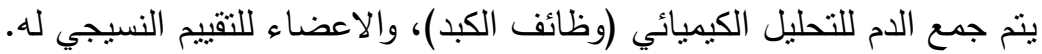

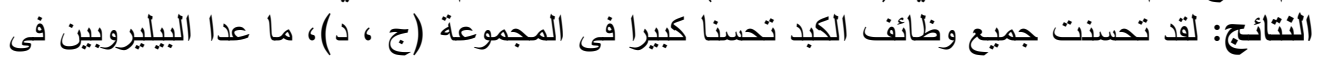

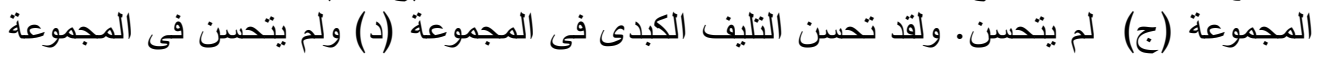

الاستنتاج: العلاج بالخلايا الجذعية يقلل التليف الكبدى ويحسن جميع وظائف الكبد لذلك الخلايا

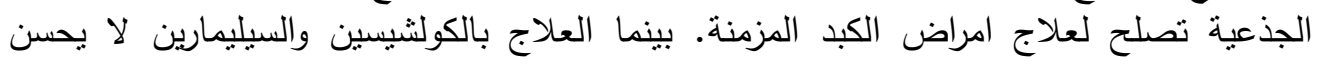

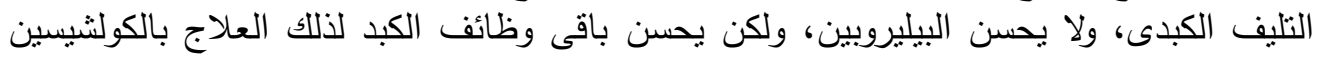

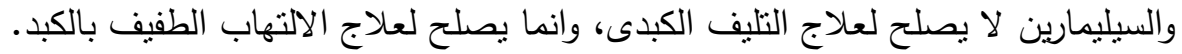

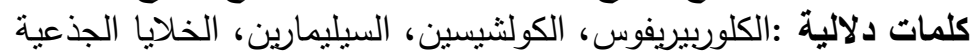

